\title{
The Application of Social Marketing to Change Smoking Behavior of Students in Traditional Islamic Boarding Schools in Aceh
}

\author{
Ismail Ismail ${ }^{1,2 \star}$, Teuku Tahlil ${ }^{3}$, Nurussalam Nurussalam ${ }^{4}$, Zurnila Marli Kesuma $^{5}$ \\ ${ }^{1}$ Department of Mathematics and Applied Sciences, Graduate School of Mathematics and Applied Sciences, Universitas Syiah \\ Kuala, Banda Aceh, Aceh, Indonesia; ${ }^{2}$ Department of Nursing, Polytechnic of Health, Ministry of Health, Aceh, Indonesia; \\ ${ }^{3}$ Department of Community Health Nursing, Faculty of Nursing, Universitas Syiah Kuala, Aceh, Indonesia; ${ }^{4}$ Department of \\ Nursing, Faculty of Nursing, Airlangga University, Surabaya, Indonesia; ${ }^{5}$ Department of Statistics, Faculty of Mathematics and \\ Natural Science, Universitas Syiah Kuala, Aceh, Indonesia
}

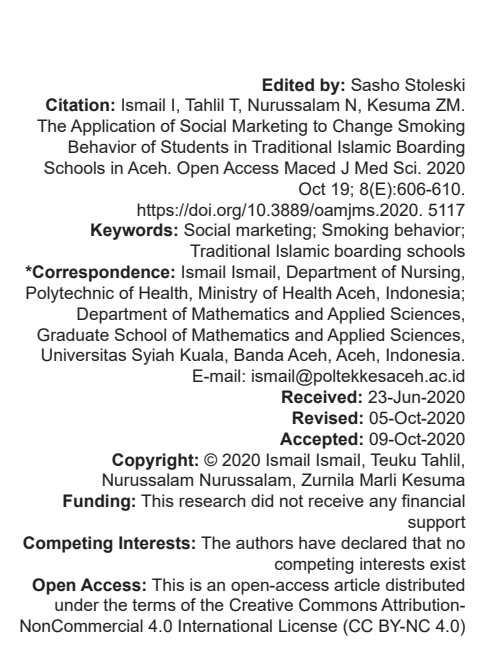

\section{Introduction}

The number of smokers in Indonesia reaches 62 million and ranks first in Southeast Asia as the country with the highest number of smokers. Indonesia ranks first in the world for the percentage of male smokers over the age of 15 , reaching $76.2 \%$ [1]. Ministry of Health (2015) states that in 2030 it is estimated that the number of deaths in the world due to cigarettes reaches ten million, 70 percent of which are developing countries [2]. The increasing number of cigarette consumption will have a direct impact on the increasing number of cigarette production every year. The problem of students at this time is really very alarming. More and more students' misbehavior is happening now that their behavior can be risky to health, one of which is smoking behavior. Many factors influence the decision to smoke, including cultural norms and habits of friends and family members [3].

At present, smoking is carried out by various age groups, especially teenagers, to early adulthood. The adolescent and early adult age groups are the most vulnerable to the influence of the environment. The behavior of parents and friends may have a big impact on the decision to start smoking [4]. The use of tobacco products is a major cause of morbidity and mortality in chronic diseases. Most smokers start smoking since childhood and adolescence [5]. The incidence of smoking among adolescents is significantly correlated with the incidence of smoking among friends and family members [6]. Besides, peer interaction and teacher involvement influence smoking behavior. Smoking prevalence in adolescents is related to smoking habits of parents and knowledge of harmful effects [7]. Smoking causes psychological disorders such as 
anxiety, depression or sadness, anger, anxiety, difficulty concentrating, and compulsive behavior [8]. Active smokers have a greater risk of insomnia compared to nonsmokers [9]. Smoking can also increase negative feelings on days with stressors [10].

Currently, smoking is practiced by students at Islamic boarding schools in Aceh. Students studying in Islamic boarding schools are in the adolescent age range with different characteristics; dependence on cigarettes among students is serious attention; the smoking strain of the students is not only influenced by parental factors but is also influenced by interactions with the microenvironment. Efforts have been made to reduce tobacco consumption among students and introduce awareness programs to change their health risk behavior [11]. One effort to reduce cigarette consumption among students is by applying a social marketing approach. Social marketing has been widely applied for more than three decades in the field of public health in an effort to change people's behavior [12]. The aim of this research analyzes the effect of applying social marketing to change smoking behavior in traditional Islamic boarding schools.

\section{Methods}

To understand this effectiveness, the research used descriptive qualitative phenomenological methods. In the qualitative approach, the study of phenomenology is used by building an understanding of reality from the point of view of social actors who experience events in their lives. The study of phenomenology is to describe the meaning of the experience for a number of individuals regarding a phenomenon [13]. Data collection is done by observation, document analysis, and interviews. Deep observations were made by observing the school environment related to no-smoking warnings and other signs in the school environment related to efforts to prevent smoking behavior. Document analysis is done by analyzing documents owned by the school related to regulations, education, and activity reports containing content related to preventing the smoking behavior of students. In-depth interviews were conducted with research informants using in-structured semi-structured interview guidelines. Informants in phenomenology research are all individuals who represent people who experience the phenomenon and were selected by purposive sampling of 25 people. The informants consisted of parents, school principals, teaching staff, local government, education offices, students, and others. Data analysis was performed using thematic content analysis techniques, a method to explain the content of findings in accordance with a predetermined theme.

\section{Results}

\section{Marketing mix and the meaning of smoking for students in Islamic boarding schools}

The marketing mix is a combination strategy carried out in the marketing field. In general, the marketing mix consists of four components (4P), namely product, price, place, and promotion. The product in this research is the message conveyed to change the smoking behavior of Islamic boarding school students. Then price represents the cost for the campaign needed to change smoking behavior. The place is the location related to how to convey information about smoking behavior rules. The product is a process that gives a number of values to the students at the Islamic boarding school students to change their smoking behavior. The meaning of smoking for students is analyzed following a systematic procedure of transcendental phenomenological data analysis. The procedure begins with an epoche, which is the stage where the researcher sets aside as many prejudices or views as possible about the phenomena of shopping among students and focuses on the views reported by the informant. The next stage of the analysis begins with identifying statements from informants, grouping statements in units of meaning and synthesizing themes into a description of individual experiences (textural and structural descriptions), and constructing a combined description of the meanings and essence of the experience of informants.

Content analysis is research that is an in-depth discussion of the content of information obtained from the results of the analysis in the field (Table 1). Social marketing is expected to change the smoking behavior of students in Islamic boarding schools in Aceh. As part of the marketing concept in its application, social marketing also relies on four components, including product, price, place, and promotion. Products are defined as anything that is used to minimize the use of cigarettes among students. Products can be in the form of mutually agreed-upon rules and restrictions. Price in the social marketing concept is a cost or sacrifice that must be incurred by the pesantren to carry out the rules. Location and distribution channels related to how to convey the rules to students. Promotion is communication that provides a convincing explanation of the rules to the students.

The results of the analysis show that smoking behavior among students has been carried out early on, especially when there is a problem. The problems faced by Students are very diverse such as problems related to economics, family problems, and romance. There are several stages experienced by smokers to become the stage of dependency. Most of the students started smoking because they were curious or wanted to try and most of the examples of smoking when being with friends. This research reveals that there 
are reasons behind the example for smoking both originating from within the sample, such as getting pleasure and relieving stress, or originating from outside the sample as invited by friends. Examples in this study also assume that smoking does not interfere with friendship; people will not be shunned and is not negative activities. Part of the students also said that smoking does not interfere with health. This is because there is no understanding of the dangers of smoking and sanctions to stop smoking. Origin of cigarettes the usual example of getting cigarettes in two ways, buy and give by friends. Examples can buy cigarettes individually or collectively (joint venture) with their friends. The interesting thing that was found was the assumption that the joint venture to buy cigarettes was a form and proof of solidarity with their group, so they did not question who would pay more or who would consume more cigarettes. The absence of sanctions has led to an increase in smokers among students. But beyond that, there are a number of boarding schools that still impose regulations that students who smoke still apply sanctions. Some boarding schools stated that there were efforts to prevent students from smoking by involving teachers, intra-school organizations, and the general public to report and take pictures whenever there were smoking students. The majority of informants said that they need to prevent smoking behavior was implemented in schools. This was revealed for a variety of reasons where among them smoking could interfere with health and also interfere with student productivity in attending teaching and learning activities. Other informants also said that the policy of controlling cigarette consumption in schools can protect nonsmokers from smoking cigarette smoke or becoming passive smokers.

The results of interviews with various elite internal boarding school, it is known that most support the installation of smoking bans in the form of leaflets and brochures. During this time, in several Islamic boarding schools in Aceh, no sign of a smoking ban has been installed at the Islamic boarding schools. Not aware of the MUI fatwa and customary rules about smoking bans. There must be an in-depth study of the Quranic verse and the hadith about the smoking ban. The Indonesian Ulema Council (MUI) has made a decision regarding the smoking fatwa contained on January 31, 2009, Smoking Fatwa Decree, that smoking is forbidden: If it is done in a public place, for children and for pregnant women. Based on the decision of the fatwa, every example in this study is categorized as unlawful for smoking. Haram in Islam is interpreted as something that is done, including sin, so as Muslims, it is fitting not to smoke and stop smoking.

However, despite the risks and fatwa, smoking behavior in Indonesia is still very high even it is always increasing every year. Smoking fatwa knowledge is also thought to shape a person's smoking behavior so that it becomes a person's consideration in forming an intention to stop smoking. The need for health education about the dangers of smoking for students. However, it was revealed that there were several obstacles in the implementation of health education. One of them is parents and the council of teachers in the market sometimes smoke. Social marketing can use several tactics to educate targets on the health hazards of smoking. Some tactics might be personal meetings, group discussions, distribution of antismoking materials (pamphlets, brochures, handouts, etc.), media advertisements, posters, and essay writing competitions at school/college kids not to smoke.

\section{Discussion}

Data on the prevalence of smokers in Indonesia can be said to be quite large, even though there are field facts that reveal the presence of harmful compounds in cigarette content. At present, smoking is practiced by students in the Islamic boarding schools in Aceh. Life in a traditional boarding school environment is very different from modern Islamic boarding schools. The role of smoking among students is influenced by problems faced by students such as economic problems, family problems, and romance. The strong intention to smoke affects smoking behavior among students. Weak implementation of regulations and sanctions is still considered weak against students. The students admitted that initially, he started smoking because of the intention to try and support friends around. The intention to smoke becomes an internal factor that will shape the students' smoking decisions. The intention itself is formed through rational choices in the decision-making process [14].

Otherwise, the intention to stop smoking is influenced by risk perception [15]. The intention to stop smoking is related to the inability to buy cigarettes and the perception of risk in social matters [16]. Knowledge of smoking fatwa and all its aspects in this study are not related to quitting intention and have no effect on the intention to stop smoking. This allegedly because of the students' knowledge of the smoking fatwa from MUI which is still very limited [17]. Muslim religion and religiosity related to the intention to stop smoking and that Muslim perception about the prohibition of cigarettes have a positive influence on efforts to stop smoking [18]. Knowledge of smoking haram fatwa that does not affect smoking is suspected because the nature of fatwa is only morally binding and the decision to follow or not is an individual choice [19]. The following will be put forward several fatwas from leading scholars regarding the law of cigarettes: "Smoking is haram, as well as trading it." As has been narrated in a hadith: "Not (may do/use something that is) dangerous or dangerous" (Ahmad's narration in his Musnad, Malik, and Atturmuzi). 
There are still differences of opinion about the law smoking among the scholars, so smokers tend to choose according to their desire [17]. To prevent the increase in smoking behavior among students, smoking policy prevention policies are needed to be implemented in boarding school. Cigarette consumption control policies in boarding schools can protect non-smokers from smoking cigarette smoke. The application of social marketing in the environment is currently one of the solutions taken by boarding school to reduce smoking behavior. The application of social marketing in the boarding school environment can be carried out easily because students who live in the boarding school. Social marketing requires the use of "branding" as a health promotion strategy [20]. Social marketing campaigns must involve key stakeholders, including policymakers, health service providers, and the community [21].

The effectiveness of social marketing is very dependent on the effectiveness of communication by inviting students to behave healthily, giving knowledge of smoking the danger of smoking, and the strengthening of regulations. Efforts to strengthen regulations on sanctions for students who smoke outside the boarding school can collaborate with community around the school smoking behavior. The majority of smokers want to quit but the knowledge about smoking cessation and stop assistance offered to smokers is low [22]. Deliver educational programs and seminars that encourage smoking cessation to youth groups [23]. Every antismoking campaign must involve ongoing teacher training to increase their awareness of the dangers of

Table 1: Analysis and Content Results on the meaning of smoking

\begin{tabular}{|c|c|c|}
\hline Theme & Reality & Category \\
\hline $\begin{array}{l}\text { Smoking has been } \\
\text { done early, especially } \\
\text { when there are } \\
\text { problems }\end{array}$ & $\begin{array}{l}\text { Smoking from an early age } \\
\text { Smoking when there is a problem }\end{array}$ & Habit \\
\hline $\begin{array}{l}\text { Smoking does not } \\
\text { interfere with health }\end{array}$ & $\begin{array}{l}\text { Smoking does not interfere with } \\
\text { health }\end{array}$ & Not a problem \\
\hline $\begin{array}{l}\text { Need to provide an } \\
\text { understanding of the } \\
\text { dangers of smoking } \\
\text { and sanctions to stop } \\
\text { smoking }\end{array}$ & $\begin{array}{l}\text { To stop smoking must be given an } \\
\text { understanding of the dangers of } \\
\text { smoking stop smoking if there are } \\
\text { sanctions } \\
\text { Support the application of smoking } \\
\text { bans will follow the direction of Telugu } \\
\text { or complain about smoking bans }\end{array}$ & $\begin{array}{l}\text { Need information } \\
\text { Support the application } \\
\text { of sanctions }\end{array}$ \\
\hline $\begin{array}{l}\text { Supports the } \\
\text { installation of } \\
\text { smoking bans, } \\
\text { leaflets, and } \\
\text { brochures }\end{array}$ & $\begin{array}{l}\text { There has not been a sign of a } \\
\text { smoking ban at the Islamic boarding } \\
\text { schools } \\
\text { Agree to install a smoking ban } \\
\text { Agree to attach leaflets or brochures } \\
\text { around the Islamic boarding schools }\end{array}$ & $\begin{array}{l}\text { Supports attachment or } \\
\text { installation }\end{array}$ \\
\hline $\begin{array}{l}\text { Not yet aware of the } \\
\text { religious prohibition } \\
\text { on smoking } \\
\text { but supports its } \\
\text { implementation }\end{array}$ & $\begin{array}{l}\text { Not aware of the MUI fatwa and } \\
\text { qanun about smoking bans } \\
\text { There must be an in-depth study of } \\
\text { the Quranic verse and the hadith } \\
\text { about the smoking ban } \\
\text { Through the ljtema Ulama of the } \\
\text { 3rd MUI Fatwa Commission, 24-26 } \\
\text { January } 2009 \text { in West Sumatra, it was } \\
\text { determined that smoking is haram } \\
\text { for children, pregnant women, and } \\
\text { smoking in public places. The reason } \\
\text { for this prohibition is because smoking } \\
\text { is an act of harming }\end{array}$ & Information needs \\
\hline $\begin{array}{l}\text { The need for health } \\
\text { education about the } \\
\text { dangers of smoking } \\
\text { for students and their } \\
\text { environment }\end{array}$ & $\begin{array}{l}\text { Supporting health seminars about } \\
\text { smoking } \\
\text { The speakers at the seminar were } \\
\text { health workers and religious leaders }\end{array}$ & Information needs \\
\hline
\end{tabular}

smoking [24]. Preventive counseling and psychiatric services must be an integral part of clinical facilities that treat secondary school students [25].

Reducing the level of cigarette use before quitting will provide a better opportunity for successful quitting later [26]. An effective smoking prevention program must take into account the dominant influence of peer groups on the onset and continuation of smoking [27]. The implementation of tobacco use prevention programs for students must be done with an emphasis on the role of smokers "parents at home and friendships [28]. Social marketing campaigns must enter into the realm of the Islamic boarding school curriculum. Inclusion of a smoking hazard curriculum is essential to increase students" knowledge of hazards smoking and improve their attitude in refusing cigarettes. The limitation of this study is that respondents were selected by percussive sampling, so the results of the study cannot be generalized to the same population.

\section{Conclusion}

The Traditional Islamic Boarding Schools agreed to implement social marketing as a behavior change intervention smoking among santri at Traditional Islamic Boarding Schools in aceh. For this reason, it is hoped that the intervention will be carried out by involving the pesantren both internally and externally.

\section{References}

1. Global Youth Tobacco Survey Collaborative Group. Global Youth Tobacco Survey (GYTS): Indicator Definitions. Atlanta, GA: Centers for Disease Control and Prevention; 2014. https:// doi.org/10.1016/j.ypmed.2008.08.004

2. World Health Organization SEARO. World Health Organization Global Youth Tobacco Survey (GYTS): Indonesia Report, 2014. New Delhi: World Health Organization SEARO; 2015.

3. Saunders C. Access to cigarettes by daily smokers in Florida's public middle schools and high schools. Nicotine Tob Res. 2011;13(7):589-98. https://doi.org/10.1093/ntr/ntr047 PMid:21460382

4. Damas C, Saleiro S, Marinho A, Fernandes G, Gomes I. Smoking habits in secondary school students. Rev Port Pneumol. 2009;15(1):43-53. https://doi.org/10.1016/ s2173-5115(09)70087-9

PMid:19145386

5. Mashita RJ, Themane MJ, Monyeki KD, Kemper HC. Current smoking behaviour among rural South African children: Ellisras longitudinal study. BMC Pediatr. 2011;11:58. https://doi. org/10.1186/1471-2431-11-58 PMid:21699687

6. Rezaeetalab F, Rezaeitalab F, Soltaneefa A, Ghaznavi M, Bakhshandeh T, Saberi S. The effect of smoking by family 
members and friends on the incidence of smoking among high school students. Pneumologia. 2012;61(4):234-6.

PMid:23424948

7. Okagua J, Opara P, Alex-Hart BA. Prevalence and determinants of cigarette smoking among adolescents in secondary schools in Port Harcourt, Southern Nigeria. Int J Adolesc Med Health. 2016;28(1):19-24. https://doi.org/10.1515/ijamh-2014-0066 PMid:25720044

8. Liem A. Pengaruh nikotin terhadap aktivitas dan fungsi otak serta hubungannya dengan gangguan psikologis pada pecandu rokok. J Buletin Psikol. 2010;18(2):37-50

9. Rompas G, Engka N, Pangemanan D. Dampak merokok terhadap pola tidur. J E Biomed. 2013;1(1):276-83. https://doi. org/10.35790/ebm.1.1.2013.4359

10. Aronson KR, Almeida DM, Stawski RS, Klein LC, Kozlowski LT. Smoking is associated with worse mood on stressful days: Results from a national diary study. Ann Behav Med. 2008;36(3):259-69. https://doi.org/10.1007/s12160-008-9068-1 PMid: 19067100

11. Rozi S, Butt ZA, Akhtar S. Correlates of cigarette smoking among male college students in Karachi, Pakistan. BMC Public Health. 2007;7:312. https://doi.org/10.1186/1471-2458-7-312 PMid:17976241

12. Smith WA. Social marketing: An overview of approach and effects. Inj Prev. 2006;12(1):i38-43.

PMid: 16788110

13. Creswell JW. Research Design: Qualitative, Quantitative and Mixed Methods Approaches. $4^{\text {th }}$ ed. London: Sage Publications Ltd.; 2014.

14. Hennessey S, Yun D, Macdonald RM, James-Maceachern M The effects of advertising awareness and media form on travel intentions. J Hosp Mark Manage. 2010;19(3):217-43. https://doi. org/10.1080/19368621003591335

15. Savoy E, Reitzel LR, Scheuermann TS, Agarwal M, Mathur C, Choi WS, et al. Risk perception and intention to quit among a tri-ethnic sample of nondaily, light daily, and moderate/heavy daily smokers. Addict Behav. 2014;39(10):1398-403. https://doi. org/10.1016/j.addbeh.2014.05.002 PMid:24926907

16. Fagan $\mathrm{P}$, Augustson $\mathrm{E}$, Backinger $\mathrm{CL}$, O'Connell $\mathrm{ME}$, Vollinger RE Jr., Kaufman A, et al. Quit attempts and intention to quit cigarette smoking among young adults in the United States. Am J Public Health. 2007;97(8):1412-20. https://doi. org/10.2105/ajph.2006.103697

PMid:17600244

17. Byron MJ, Cohen JE, Gittelsohn J, Frattaroli S, Nuryunawati R, Jernigan DH. Influence of religious organisations' statements on compliance with a smoke-free law in Bogor, Indonesia: A qualitative study. BMJ Open. 2015;5(12):e008111. https://doi. org/10.1136/bmjopen-2015-008111

PMid:26667011

18. Yong HH, Hamann SL, Borland R, Fong GT, Omar M. ITC-SEA project team. Adult smokers' perception of the role of religion and religious leadership on smoking and association with quitting: $A$ comparison between Thai Buddhists and Malaysian Muslims.
Soc Sci Med. 2009;69(7):1025-31. https://doi.org/10.1016/j. socscimed.2009.07.042

PMid:19695758

19. Boulos DN, Loffredo CA, El Setouhy M, Abdel-Aziz F, Israel E, Mohamed MK. Nondaily, light daily, and moderate-to-heavy cigarette smokers in a rural area of Egypt: A populationbased survey. Nicotine Tob Res. 2009;11(2):134-8. https://doi. org/10.1093/ntr/ntp016

PMid:19246629

20. Evans WD. How social marketing works in health care BMJ. 2006;332(7551):1207-10. https://doi.org/10.1136/ bmj.332.7551.1207-a

PMid:16710002

21. Suarez-Almazor ME. Changing health behaviors with social marketing. Osteoporos Int. 2011;3:461-3. https://doi. org/10.1007/s00198-011-1699-6

PMid:21847766

22. Kralikova E, Kmetova A, Zvolska K, Blaha M, Bortlicek Z. Czech adolescent smokers: Unhappy to smoke but unable to quit. Int J Tuberc Lung Dis. 2013;17(6):842-6. https://doi.org/10.5588/ ijtld.12.0753

PMid:23676173

23. Unsal M, Hamzacebi H, Dabak S, Terzi O, Kirisoglu T. Smoking status and levels of knowledge regarding cigarettes among primary school teachers. South Med J. 2008;101(12):1227-31. https://doi.org/10.1097/smj.0b013e31818da807 PMid:19005425

24. Almutairi KM. Smoking among Saudi students: A review of risk factors and early intentions of smoking. J Community Health. 2014;39(5):901-7. https://doi.org/10.1007/s10900-014-9909-8 PMid:24984600

25. Amin TT, Amr MA, Zaza BO, Suleman W. Harm perception attitudes and predictors of waterpipe (shisha) smoking among secondary school adolescents in Al-Hassa, Saudi Arabia. Asian Pac J Cancer Prev. 2010;11(2):293-301. https://doi.org/10.1007/ s10865-011-9319-7

PMid:20843104

26. Feng $\mathrm{G}$, Jiang $\mathrm{Y}, \mathrm{Li} \mathrm{Q}$, Yong $\mathrm{HH}$, Elton-Marshall $\mathrm{T}$, Yang $\mathrm{J}$, et al. Individual-level factors associated with intentions to quit smoking among adult smokers in six cities of China: Findings from the ITC China survey. Tob Control. 2010;2(2):i6-11. https:// doi.org/10.1136/tc.2010.037093

PMid:20935198

27. Can G, Topbas M, Oztuna F, Ozgun S, Can E, Yavuzyilmaz A. Factors contributing to regular smoking in adolescents in Turkey. J Sch Health. 2009;79(3):93-7. https://doi. org/10.1111/j.1746-1561.2008.0392.x PMid: 19207514

28. Baheiraei A, Soltani F, Ebadi A, Cheraghi MA, Foroushani AR. Family and peer risk factors as predictors of lifetime tobacco use among Iranian adolescents: Gender similarities and differences. Glob J Health Sci. 2014;6(4):63-75. https://doi.org/10.5539/ gjhs.v6n4p63 PMid:24999129 